\title{
MODULAR APPROACH TO MINORITY LANGUAGE TEACHING/LEARNING: KNOWLEDGE AT THE HEART OF LEARNING
}

У овом раду направљен је предлог за модуларни приступ двојезичној/вишејезичној настави и учењу од стране изворних говорника мањинских језика, у коме се ученици подстичу да користе све језике који су им на располагању (мањинске и већинске језике), и на који додају страни језик који сматрају корисним за своју будућу друштвену, професионалну или академску мобилност. Све то има за циљ да помогне ученицима из етнолингвистичких мањина да замисле жељеног себе, себе какав треба бити (Dörnyei 2005; Dörnyei\& Ushioda, 2009), што им помаже да добију самопоуздање, да препознају своју сопствену вредност, да прошире своје компетенције, побољшају когнитивне стратегије и вештине учења, постану аутономнији ученици и покажу решеност да остану у школи дуже од оних који су изложени традиционалном наставном контексту на већинском (или чак само на мањинском) језику. Модуларни приступ са знањем у срцу учења само је један од начина развијања нових писмености које су признате као једна од потребних вештина за 21. век, уз решавање проблема и критичко размишљање, које једино може бити развијено у оквиру конструктивног, контекстуалног приступа изградњи знања у коме су замагљене границе између наставника и ученика и између језика који су присутни у учионици. Садашње стање образовне језичке политике у Србији у вези са овим питањем, дато је како би илустровало тачке о којима је реч.

Кључне речи: мањински језици, етнолингвистичке мањине, двојезично/ вишејезично образовање, конструктивна генерација знања, колаборативно учење и настава, модуларни приступ настави и учењу, образовна језичка политика и планирање у Србији.

\section{General considerations: European paradigm of language learning and teaching}

Language education policy and planning, as integral parts of general language policy and planning have been in the focus of European political, cultural and educational institutions for decades. In view of the ideology of European citizenship, a unified European academic space, 
aligned with the concepts of language human rights and maintenance/ revitalization of dominated languages, on one hand, and the overarching presence of English as a global lingua franca, on the other, language has been recognized as the key social activity of any human existence. Furthermore, language education has been understood as an interdisciplinary and transdisciplinary socially engaged paradigm in which a wide range of stakeholders need to be involved beyond the traditional notion of language teachers and language planners, on one hand, and language students on the other (Filipović, 2015a, 2015b, Vez, 2009). Minority language education has, against such a socio-historical and political background, at least overtly and de iure, become one of the indispensable and essential components of most European language education policy and planning documents and legislation.

One logical implication, often cited in pan-European documents regarding language education in general, and minority language education in particular, is that plurilingulism on an individual level, interpreted as a person's ability to use a variety of languages in line with her or his personal, affective, professional, academic and other needs, can and should be developed through plurilingual education (Sheils, 1999; Council of Europe, 2001; 2007; European Commission, 2007; Vez, 2009; Filipovic \& Vuco, 2012, etc.).

As Vez (2009: 11) points out, "The Council of Europe (CE), including now (end of 2008) 47 member States, is very active in enhancing Europe's cultural heritage and promoting unity in diversity particularly in educational fields. The $\mathrm{CE}$ has long run cross-European projects focusing on the transmission of democratic values to young people and their preparation for life in a multilingual and multicultural Europe (Council of Europe, 2000)". All these long-term measures aim at promoting largescale plurilingualism and multilingualism through high quality formal education, available to every and all citizens of Europe, which diversify the scope of official languages of education, as well as additional/foreign/minority languages by supporting official institutions of language policy and planning and political bodies in member states, which should promote language(s) learning from day 1 in a young person's educational life. The principal objective of these institutional measures is to raise 
generations of young people with heightened levels of intercultural and linguistic awareness and tolerance for languages and language speakers belonging to socially and politically less influential groups and communities, and vice versa.

Continuous language teacher education and elaboration and coordination, "of networks for the design and implementation of modular courses" (Vez, 2009: 11) is also among the key initiatives cited in most European documents. Content and Language Integrated Learning (CLIL) is one of the innovative conceptual approaches developed over the last decade with the general aim of improving and further enhancing plurilingual and pluricultural education focusing on teaching contents presented in two or more languages within the same classroom. As defined in the ECML publication, "CLIL is a dual-focused educational approach in which an additional language is used for the learning and teaching of content and language with the objective of promoting both content and language mastery to predefined levels." (ECML, online document, p. 11) It specifically targets some of the key competences for European lifelong learning, such as linguistic competences in more than one language, grounded academic and professional experience, situated knowledge generation and construction, learner autonomy and learning outcomes/competences which can be applicable and expanded in reallife professional, academic and private spheres of life (ECML, online document, pp. 11-13)

\section{Minority languages within the general framework of European language education: Serbia as a case study}

Serbia, like most of the other member states of the Council of Europe and among the 25 countries which have ratified the European Charter for Regional or Minority Languages has developed extensive legislative instruments which target ethnolinguistic communities recognized by the Serbian Constitution, in all domains of language use, including formal education. And, as in most other educational systems, minority languages are present to varying degrees and with different functional loads within Serbian formal primary and secondary schooling. 
1. Education in L1: when it comes to ethnolinguistic minorities whose languages are different from the majority language, though Serbian is officially recognized as the principal language of education, these communities are nonetheless entitled to primary and secondary education in their mother tongue if and when students and their parents desire it, and if a sufficient number of qualified teaching staff and good quality teaching materials in the target language are available. In the case of Serbia, only the 'more powerful' minority groups, such as Hungarians, Romanians, and Slovaks, exercise this right to the full extent envisaged by law (Council of Europe, 2014).

2. Education in the majority language, in our case Serbian as the official language of education, is a second option assured by the official language education policy. Research by a number of authors (Mikeš, 2001, Filipović, 2009, Filipović et al. 2007) indicates that in many cases members of ethnolinguistic communities opt to send their children to mainstream schools in order to assure their social mobility at higher levels of the educational system. Namely, there are very few university programs offered in minority languages, which makes members of ethnolinguistic minorities highly vulnerable when it comes to engaging to the full extent of their academic capacities due to their lack of cognitive academic language proficiency (CALP). CALP is defined by Cummins (2008: 71) as the "students' ability to understand and express, in both oral and written modes, concepts and ideas that are relevant to success in school". It implies the presence of linguistic and sociocultural competences in different academic registers and terminology corpora, as well as the possession of the stylistic and structural means which are to be applied in written and oral discourses most commonly recognized as academic speaking and writing. This further suggests that general communicative proficiency in the language of education (when it is not one's native language) is often deceptive according to Cummins (2008: 75) drawing on research by Vincent (1996): "The children seem to have much greater English proficiency than they actually do because their spoken English has no accent and they are able to converse on a few everyday, frequently discussed subjects. Academic language is frequently lacking. Teachers actually spend very little time talking with individual 
children and tend to interpret a small sample of speech as evidence of full English proficiency. (p. 195)" The situation outlined in the previous sentences has been identified as subtractive bilingualism (Wright et al., 2000; Filipović, 2009; Scutnabb-Kangas, 1981) which, with time, decreases a student's competence in their L1, while at the same time not reaching the academic linguistic adequacy in the majority language as the language of education (Cummins, 2008).

3. Bilingual education has been recognized by European institutions as one of the key instruments for the affirmation of plurilingualism, pluriculturalism, and for the creation of more socially just educational systems in which there is space and purpose for a larger number of languages within the same classroom. However, even though the Serbian legislature recognizes the importance of this type of education, the minority languages have been purposefully excluded from the latest educational efforts to assure high quality bilingual education based on CLIL which is now available for Serbian and the foreign languages present in our educational system.

In other words, as will be presented in the following section, there is a huge discrepancy between the officially promoted, explicit language education policies, and the interests of different stakeholders which often have a direct impact on the formulation of policies at governmental level, or impede their implementation at the local level.

\section{Bilingual/plurilingual education and minority languages: pros and cons from the Serbian perspective}

Everybody would agree that bilingual education has tremendous potential for both the students and the community. This is even more important for students from ethnolinguistic minority groups, as bilingual education is said to promote equal access to high quality education for all, open up space for social and professional mobility and encourage learner autonomy, personal growth, and social and cultural integration. It is also often repeated that language teachers need to be continuously educated and allowed access to high quality lifelong learning programs which would help them better understand the advantages of bilingual (or 
plurilingual) education and learn how best to use the resources available in order to achieve optimal results in their classrooms, based on policies defined and designed by policy makers who have the same degree of awareness of this important educational issue.

However, real life often does not agree with our best intentions, or the general guidelines defined by supranational institutions and backed by academic research. In the first place, there is the question of political will and openness to policy dialogues as well as the readiness to examine and evaluate different educational perspectives, which require joint efforts from educational, academic and political institutions. This also implies the need to develop and recognize bottom up language education policies, based on the needs of local and regional stakeholders, which are still often rejected by the political and educational elites. Furthermore, serious curricular issues need to be addressed if successful and purposeful bilingual/plurilingual education is to be implemented, related to the number of languages involved, their role and function within the educational process (such as whether there will be one primary language in the classroom, and whether that would be a minority or a majority language, which language(s) will be used for which educational subjects, in what proportions, and whether minority language(s) will find their place along with the foreign languages within the CLIL based curriculum all throughout the educational process, or if they will appear only in the first years of minority students' education as vehicular languages which should lead to development of academic linguistic competences in majority and foreign languages). The question of teaching contents is closely related to the curriculum and there is often a lack of serious correlation between the teaching materials and the students' real-life needs, especially when it comes to ethnolinguistic minorities with relatively specific cultural models more or less different from those of a given majority community. Moreover, minority languages often carry the stigma of being non-standardized varieties, not deemed 'worthy' of functioning as languages in more formal domains, such as education. Their low social status makes for an excellent quasi-scientific argument that they should not be implemented as languages of literacy in formal education. 
In Serbia, all the above issues were encountered during the process of preparation of the above cited Guidelines for bilingual education which specify the conditions for the implementation of a CLIL based bilingual education. A committee was set up by the Ministry of Education, Science and Technological Development of the Republic of Serbia comprising of members from academia (from different ethnic groups) and political representatives of a small number of (larger) ethnic minorities. Members of those larger minority communities (such as the Hungarians) refused to apply the concepts of bilingual education in the schools where their languages are taught, worrying that the education in a minority language as L1 would be jeopardized by the introduction of bilingual Serbian/minority/foreign language education! On the other hand, members from the most stigmatized ethnic minority, the Romani community, provided argumentation related to the problems of not having a well defined corpus of standard Romani in Serbia, which for decades has been an excuse not to publish teaching materials or train teachers who would be competent in carrying out formal education in Romani. The Ministry hid behind the expert opinion of the European policy makers stating that minority and foreign languages cannot be treated the same as that would threaten the status and the relevance of minority languages in the Serbian educational system! All that, while the empirical evidence from different parts of Serbia indicates a serious decline in the interest in education in minority languages in favor of monolingual education in Serbian and, when available, Serbian/foreign language bilingual education. If we take a look at the table representative of Vojvodina alone, from the Third periodical report on the implementation of the Charter for regional or minority languages in Serbia (2014), we can easily see that, except in the case of the Hungarians, and partially the Slovaks and Romanians, members from other ethnolinguistic minorities did not attend classes in their L1 in any significant numbers: 


\begin{tabular}{|c|c|c|c|c|c|c|}
\hline \multirow[t]{2}{*}{ Nationality } & \multirow{2}{*}{$\begin{array}{l}\text { Total No. of } \\
\text { students }\end{array}$} & \multicolumn{5}{|c|}{ Language of education } \\
\hline & & Hungarian & Rumanian & Rythnian & Slovakian & Croatian \\
\hline Serbs & 107.692 & 50 & 17 & 34 & 45 & \\
\hline Albanians & 233 & 3 & & 2 & & \\
\hline $\begin{array}{l}\text { Bosnians/ } \\
\text { Muslims }\end{array}$ & 637 & 1 & & 1 & & \\
\hline Bulgarians & 61 & 2 & & & & \\
\hline Banyash & 756 & 19 & & & & \\
\hline Hungarians & 17.671 & 14.259 & 1 & 18 & 4 & 3 \\
\hline Macedonians & 576 & 2 & 2 & & & \\
\hline Germans & 108 & 1 & & & & \\
\hline Romas & 8.272 & 533 & 122 & 23 & 49 & \\
\hline Rumanians & 1.738 & 1 & 926 & & & \\
\hline Rythinians & 903 & 5 & & 393 & 1 & \\
\hline Slovaks & 3.763 & 8 & & 2 & 2.785 & \\
\hline Ukrainians & 231 & & & 2 & 1 & \\
\hline Croats & 2.563 & 18 & & 4 & 2 & 277 \\
\hline Montenegrins & 1.971 & & & & 3 & \\
\hline Undeclared & 4.520 & 175 & 3 & & 24 & 6 \\
\hline
\end{tabular}

Table 1. Education in minority languages in Vojvodina for the school year 2012/13 (source: Third periodical report on the implementation of the Charter for Regional or Minority Languages in Serbia,2014, pp.42-43 https://www.coe.int/t/dg4/ education/minlang/Report/PeriodicalReports/SerbiaPR3_ser.pdf) 


\section{What could/should be done? A modular approach to minority language teaching}

It is obvious that in the process of successful integration of minority languages into bilingual/plurilingual education, awareness-raising among educational policymakers and practitioners regarding the importance and relevance of the presence of minority languages in mainstream education represents a prerequisite for any purposeful action. In other words, top-down language education policy needs to be engaged and official language planners motivated to support this type of educational shift.

On the other hand, empowerment of minority community members is the next crucial step in this process, and they should be encouraged to take an active role in bottom-up language education policy design, development and implementation which could satisfy their members' linguistic, communicative, social, identificational, cultural, educational and professional needs.

And finally, overall community-based action is necessary, which would target all members of both minority and majority speech communities, to allow for the awareness raising among the speakers of majority languages regarding the importance and relevance of the presence of minority languages in their mainstream education, which would help them develop tools for critical analysis of the existing and proposed new language education policies.

Last, but not least, the academic community needs to be alerted to the social relevance of the issue of engaging minority languages in bilingual/plurilingual education, and should be able to competently engage in defining objectives for an integrative, effective bilingual/plurilingual education involving minority languages, applying their academic expertise and research findings to support viable and sustainable solutions provided by other social stakeholders regarding this topic. In other words, the academic community needs to be ready and capable of engaging in a truly trans-disciplinary, socially relevant, constructive dialogue which would generate new ways of thinking and interpreting the situation in the 
field and serve as an intermediary between representatives of different educational and political institutions from both minority and majority communities.

Hence, academic research apparatus, such as participatory action research (which would open space for local initiatives, leadership, creativity and innovation in real-life classrooms), curriculum design and development, teaching materials production, definition of clearly purposeful learning and teaching outcomes based on CLIL and involving issues such as which literacies in which languages should be developed during the educational process should be investigated and applied. Moreover lifelong teacher education with the continuous development and improvement of toolkits for teacher training and effective implementation of chosen methods and techniques should be stressed and supported on all levels both academically and financially. Only then can we aim at designing a language education policy which can be put into the service of sustainable presence of minority languages in formal education, aligned with supra-national proposals, such as the one designed by UNESCO in 2005 and presented here with adaptations necessary for the argumentation presented in this paper 


\begin{tabular}{|c|c|c|c|c|c|}
\hline Objectives & Contents & $\begin{array}{l}\text { Teachers } \\
\text { /methods and techniques }\end{array}$ & Resources & $\begin{array}{l}\text { Duration/ } \\
\text { quantity }\end{array}$ & Assessment \\
\hline Literacy & $\begin{array}{l}\text { Language teaching in } \\
\text { minority language by } \\
\text { level }\end{array}$ & $\begin{array}{l}\text { Minority language } \\
\text { teachers/varied methods } \\
\text { and techniques (hopefully } \\
\text { allied with state of the art } \\
\text { resources such as CEFR } \\
\text { and ELP) }\end{array}$ & \multirow{4}{*}{$\begin{array}{l}\text { General: CEFR, } \\
\text { ELP, online } \\
\text { resources by } \\
\text { the Council of } \\
\text { Europe, ECML, } \\
\text { and other } \\
\text { institutions } \\
\text { Local: } \\
\text { Libraries, } \\
\text { national } \\
\text { minorities } \\
\text { councils, etc. }\end{array}$} & $\begin{array}{l}\text { Number of hours } \\
\text { a week }\end{array}$ & \multirow[t]{3}{*}{$\begin{array}{l}\text { Development } \\
\text { of adequate } \\
\text { evaluation } \\
\text { tools }\end{array}$} \\
\hline CLIL & $\begin{array}{l}\text { Materials for teaching } \\
\text { other subjects in } \\
\text { minority language }\end{array}$ & $\begin{array}{l}\text { Minority language } \\
\text { teachers and teachers } \\
\text { of other subjects (even } \\
\text { if they do not speak the } \\
\text { minority language) } \\
\end{array}$ & & $\begin{array}{l}\text { Selection of } \\
\text { subjects; number } \\
\text { of hours a week }\end{array}$ & \\
\hline $\begin{array}{l}\text { Social Inclusion/ } \\
\text { promotion of } \\
\text { pluricultural/ } \\
\text { plurilingual } \\
\text { education }\end{array}$ & $\begin{array}{l}\text { Language and culture } \\
\text { teaching materials in } \\
\text { minority and majority } \\
\text { languages for students } \\
\text { from both minority and } \\
\text { majority groups } \\
\end{array}$ & $\begin{array}{l}\text { Minority language } \\
\text { teachers and teachers } \\
\text { of other subjects/group } \\
\text { discussions, role play, } \\
\text { projects, portfolios, etc. }\end{array}$ & & $\begin{array}{l}\text { Number of hours } \\
\text { a week }\end{array}$ & \\
\hline $\begin{array}{l}\text { Community } \\
\text { engagement }\end{array}$ & $\begin{array}{l}\text { Promotional materials } \\
\text { for parents, school } \\
\text { authorities, political } \\
\text { authorities on local and } \\
\text { regional levels }\end{array}$ & $\begin{array}{l}\text { Minority language } \\
\text { teachers and teachers of } \\
\text { other subjects/posters, } \\
\text { public debates, school } \\
\text { visits }\end{array}$ & & $\begin{array}{l}\text { Continuous } \\
\text { engagement }\end{array}$ & $\begin{array}{l}\text { Surveys, } \\
\text { questionnaire, } \\
\text { public } \\
\text { debates, etc. }\end{array}$ \\
\hline
\end{tabular}


The above table can easily be used as a checklist which can help all interested parties define their objectives, teaching and learning needs, as well as teaching methods and materials, allocate resources and make sure that the outcomes of their efforts are accurately evaluated.

The guidelines suggested in the previous paragraphs should help us develop a tentative modular approach to bilingual/plurilingual education, in which the focus is not on $a$ language or the languages, but rather on individual students and on socially constructed knowledge creation in an atmosphere in which students and teachers (of languages and other subjects) engage in collaborative processes of teaching and learning, interchanging languages of instruction in accordance with educational, motivational, emotional and other needs at either the individual or social level, as presented in Figure 1. below.

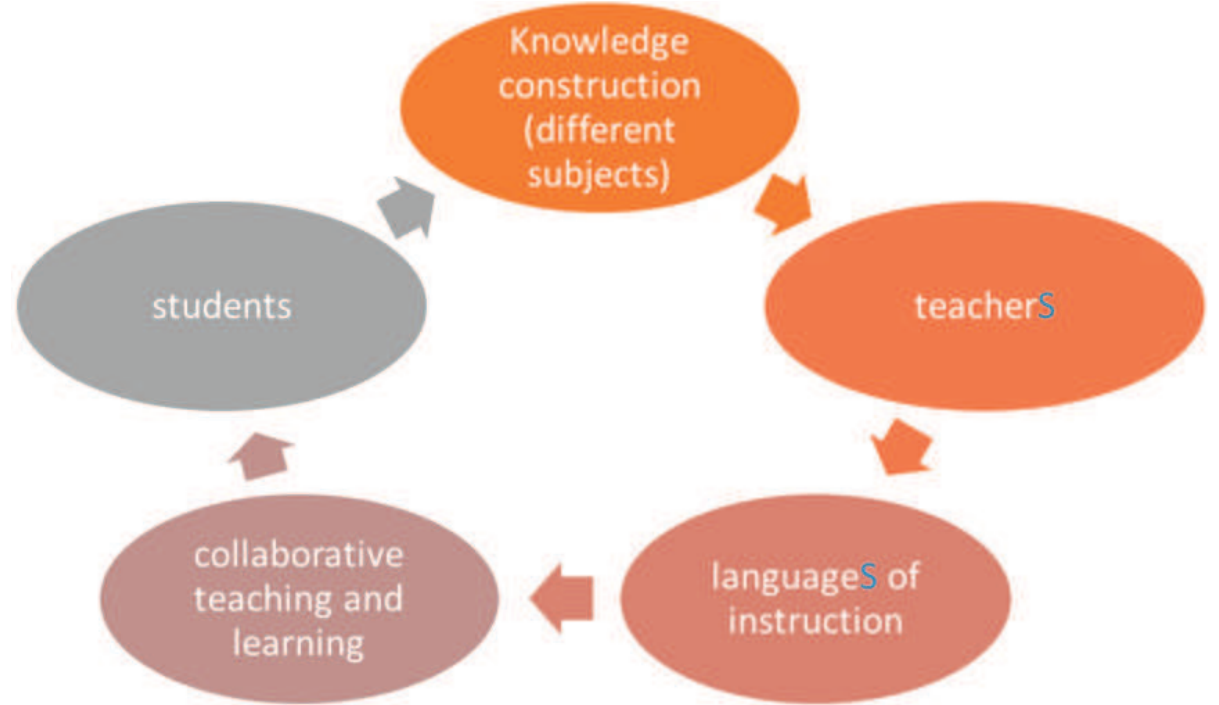

Figure 1. Modular approach to bilingual/plurilingual minority/majority/foreign language education

So, to paraphrase the ECML motto for their program campaign: Languages at the heart of learning, a modular approach to bilingual/plurilingual education should gear toward the concept of Knowledge at the heart of learning. Knowledge of languages, knowledge of subject mat- 
ter, sociolinguistic, sociocultural, pragmatic, plurilingual and pluricultural knowledge, generated in dialogical form within a classroom in which students and teachers create purposeful communities of practice. Jimenez \& Silva (2012: 336) offer an excellent definition of such a learning and teaching environment when describing the relevance of Teacher-Learner communities of practice, "through collaboration and active engagement in a community of practice, members are able to imagine themselves, their roles, and their future in the practice as they move from peripheral to full participation, or from novice to expert, in making meaning of the tools, concepts, and processes that co-construct and cultivate the practice". The meanings that can be made and negotiated in more than one language, in an atmosphere in which students are encouraged to apply all the linguistic repertoires they have at their disposal to explore and critically evaluate topics of relevance in their personal and communal contexts, which may or may be not always explicitly present in the mainstream curricula. Hence, different languages and different teachers should be involved (represented by the capital S in 'languageS' and 'teacherS' in Figure 1) in order to assure the optimal conditions for constructive, collaborative learning at all levels of education and in all subjects.

\section{Conclusions: impact of effective bilingual/plurilingual education for children from ethnolinguistic minorities}

By using all the languages the students have at their disposal (minority and majority languages), and by adding the foreign languages deemed useful for their future social, professional and academic mobility, the students are encouraged to envision their desired self, ought-to-be self (Dörnyei 2005; Dörnyei\& Ushioda 2009), which helps them gain self-confidence, become aware of their self-worth and become capable of recognizing the value of a minority culture, language, tradition, religion, etc. In terms of academic achievements, modular bilingual/plurilingual education for members of ethnolinguistic minorities helps them expand their overall competences, and improve their cognitive strategies and learning skills (especially when it comes to bridging knowledges from different subjects in different languages) It also enriches their creativity and imagination 
and such students become more autonomous learners and exhibit commitment to stay in school longer than those who are exposed to a traditional teaching context in a majority (or even only a minority language) (Thomas $\&$ Collier, 2002). The modular approach with knowledge at the heart of learning is only one of the ways of developing new literacies (Cummins, 2008), which "depend on the context of the situation, the activity itself, the interactions between participants...". The "knowledge and experiences that these various participants bring to these interactions is distant from the view held by most L2 educators who still embrace a technocratic notion of literacy and emphasize the development of decontextualized skills" (Valdés, 2004: 115, cit. in Cummins, 2008: 77). New literacies are recognized as one of the skills needed for the 21 st century, which are also geared toward problem solving and critical thinking, These can only be developed within a constructivist, contextual approach to knowledge building in which the lines between teachers and students and among the languages present in the classrooms are blurred. On a social level, this may help us achieve higher degrees of social inclusion and validation of the minority groups living among us. In that way we may be able to begin creating educational, teaching and learning environments in which languages and teaching contents are interlinked in a way that maximize the cognitive development and learning outcomes of socially marginalized or stigmatized students (see Cummins 2008 for further discussion about the future development in this field of research).

\section{References:}

Council of Europe (2001). The Common European Framework of Reference for Languages: Learning, Teaching, Assessment. Cambridge: Cambridge University Press.

Council of Europe 2007. From Linguistic Diversity to Plurilingual Education: Guide for the Development of Language Education Policies in Europe. Main version. Strasbourg: Council of Europe.

Cummins, J. 2008. BICS and CALP: Empirical and Theoretical Status of the Distinction, in:Street, B. \& Hornberger, N. H. (Eds.) Encyclopedia of Language and Education, 2nd Edition, Volume 2: Literacy. New York: Springer Science + Business Media LLC, pp. 71-83. 
Dörnyei, Z. 2005. The psychology of the language learner: Individual differences in second language acquisition. Mahwah, NJ: Lawrence Erlbaum.

Dörnyei, Z. \& E. Ushioda, (Eds). 2009. Motivation, language identity and the L2 self. Bristol:Multilingual Matters.

ECML. European framework for CLIL teacher education. Graz: ECML publication. http://clilcd.ecml.at/EuropeanFrameworkfor CLILTeacherEducation/tabid/2254/language/en-GB/Default.aspx, retrieved on March 30, 2016

European Commission 2005. Communication from the Commission to the Council, the European Parliament, the European Economic and Social Committee and the Committee of the Regions: A New Framework Strategy for Multilingualism (COM 2005, 596 final).

Filipović Jelena, Julijana Vučo, Ljiljana Djurić. 2007. Critical review of language education policies in compulsory primary and secondary education in Serbia. Current Issues in Language Planning: Vol. 8:2: 222-242.

Filipović Jelena. 2009. Moć reči: Ogledi iz kritičke sociolingvistike [The social power of words: Essays on critical sociolinguistics]. Beograd: Zadužbina Andrejević.

M. Jimenez-Silva, K. Olson. A community of practice in teacher education: insights and perceptions, International Journal of Teaching and Learning in Higher Education, Vol. 24, No.3, 335-348, 2012.

Mikeš, M. 2001. Sociolinguistic background of kindergarten children in bilingual settings. International journal of the sociology of language,m 151: 49-67.

Savet Evrope. 2014. Trreći periodični izveštaj o primeni evropske povelje o regionalnim ili manjinskim jezicima u Republici Srbiji. https:// www.coe.int/t/dg4/education/minlang/Report/PeriodicalReports/ SerbiaPR3_ser.pdf

Sheils, J. (1999). The European Language Portfolio: towards a democratic citizenship. Babylonia, 1: 6-7.

Skutnabb-Kangas, T. 1981. Bilingualism or not: The education of minorities. Clevedon, Avon, England: Multilingual Matters.

Thomas, W. P., \& V. P. Collier, 2002. A national study of school effectiveness for language minority students' long-term academic achievement. 
Santa Cruz, CA: Center for Research on Education, Diversity and Excellence, University of California-Santa Cruz.

UNESCO. 2005. First language first: Community-based literacy programmes for minority language contexts in Asia. Bangkok, Thailand: UNESCO Asia and Pacific Regional Bureau for Education Valdés, G. (2004). Between support and marginalization: The development of academic language in linguistic minority children. International Journal of Bilingual Education and Bilingualism, 7, 102-132.

Vez, J. M. 2009. Multilingual education in Europe: Policy developments. Porta linguarum, 12: 7-24.

Wright, S. C., D. M. Taylor \& J. Macarthur. 2000. Subtractive bilingualism and the survival of the Inuit language: heritage-versus second-language education. Journal of Educational Psychology,.92, (1): 63-84

\begin{abstract}
Herein, a proposal is made for a modular approach to bilingual/plurilingual teaching and learning by native speakers of minority languages, in which the students are encouraged to use all the languages they have at their disposal (minority and majority languages), and to which foreign languages deemed useful for their future social, professional and academic mobility are added. All that in order to help the students from ethnolinguistic minorities envision their desired self, ought-to-be self (Dörnyei 2005; Dörnyei\& Ushioda, 2009), which helps them gain self-confidence, recognize their selfworth, expand their competences, improve their cognitive strategies and learning skills, become more autonomous learners and exhibit commitment to stay in school longer than those who are exposed to a traditional teaching context in a majority (or even only in a minority language). A modular approach with knowledge at the heart of learning is just one of the ways of developing new literacies which are recognized as one of the skills needed for the 21 st century, along with problem solving and critical thinking, which can only be developed within a constructivist, contextual approach to knowledge building in which the lines among teachers and students and among the languages present in the classrooms are blurred. The current state of Serbian language education policy regarding this issue is provided to illustrate the points in question.
\end{abstract}

Keywords: minority languages, ethnolinguistic minorities, bilingual/plurilingual education, constructive knowledge generation, collaborative learning and teaching, modular approach to teaching and learning, Serbian language education policy and planning. 


\section{Biographical statement}

DR JELENA FILIPOVIĆ is a professor of Spanish and Sociolinguistics and a head of the Department of Iberian Studies, Faculty of Philology, University of Belgrade. She has been a visiting professor at the Graduate School of Purdue University, USA, at the Universidad Nacional Autónoma de México, and at the University of Graz, Austria. Her research interests are in the areas of critical sociolinguistics, language policy and planning, gender studies, Sephardic studies, Hispanic and applied linguistics. She has authored and co-authored several books and several dozens of articles in academic journals and monographic publications. She has been engaged in a number of national and international projects in the areas of language education policies, gender sensitive language policies, foreign and second language teaching, curriculum design and development and language maintenance and revitalization. She is an international expert of the European Center for Modern Languages and a member of the Board of Education of the Serbian Academy of Sciences and Arts.

E-mail: jelenafbgd@gmail.com 